\title{
Państwa wycofujące się z kapitałowego systemu emerytalnego na przykładzie Węgier i Chile
}

\section{Wstęp}

Reformy systemów emerytalnych w latach osiemdziesiątych i dziewięćdziesiątych XX w. w Ameryce Południowej oraz w Europie Środkowo-Wschodniej miały co do zasady zbieżne cele. Nie ulega wątpliwości, że ich wspólnym mianownikiem było wzmocnienie zależności pomiędzy uzyskiwanym wynagrodzeniem a wysokością przyszłego świadczenia, czyli transformacja z systemu zdefiniowanego świadczenia do systemu zdefiniowanej składki. Dzięki czemu ubezpieczeni mieli mieć większą motywację do pracy, a lepiej zarabiający do uczestnictwa w systemie emerytalnym i legalnego odprowadzania składek. Co poskutkowało tym, że gorzej zarabiający uzyskali niższą stopę zastąpienia a bogatsi wyższą.

Na tym podobieństwa się nie kończą, bowiem zarówno w Ameryce Południowej (z wyjątkiem Brazylii) oraz w Europie Środkowo-Wschodniej wprowadzono nowość do państwowego systemu emerytalnego w postaci filarów kapitałowych. Jednocześnie części ubezpieczonym dano wybór, czy chcą pozostać wyłącznie w repartycyjnym systemie emerytalnym, czy też w mieszanym, czyli repartycyjno-kapitałowym. Jednak, co istotne, swoboda i zakres tego wyboru różniły się znacznie w zależności od kraju.

Z kolei w inne kraje, w szczególności wysoko rozwinięte, oparły się idei wprowadzenia przymusowego filaru kapitałowego. Jest to o tyle charakterystyczne, że to właśnie te państwa (przede wszystkim USA, Wielka Brytania) byłby największymi agitatorami funduszy emerytalnych. Innymi słowy polecały krajom mniej rozwiniętym rozwiązanie, którego same nie przyjęły.

\section{Chile}

Opisane we wstępie reformy rozpoczęły się w Chile, które jako pierwsze wprowadziło obligatoryjne prywatne fundusze emerytalne, inwestujące składki ubezpieczonych na giełdzie papierów wartościowych.

Chile miało pierwszy na zachodniej półkuli system państwowych emerytur. Jego początki sięgają 1924 r., kiedy ustanowiono fundusz emerytalny dla pracowników fizycznych. W latach 50. przekształcił się w system dla wszystkich

\footnotetext{
${ }^{1}$ Doktorant w Katedrze Prawa Ubezpieczeń Społecznych i Polityki Społecznej na Wydziale Prawa i Administracji Uniwersytetu Łódzkiego.
} 
zatrudnionych. Zasadą było wypłacanie emerytur ze składek, które wpłacali aktualnie pracujący. $Z$ czasem fundusz ulegał podziałom na dziesiątki kas branżowych. Ale dwie zasady pozostawały nienaruszone: jego państwowy charakter oraz to, że aktualnie pracujący utrzymują tych, którzy zakończyli życie zawodowe. Tak samo miało być w następnych pokoleniach.

Fundamentalna reforma emerytalna w Chile została wprowadzona w $1981 \mathrm{r}$. jako element ogólnej polityki rządu generała Augusto Pinocheta zakładającej przekształcenie chilijskiej gospodarki w kierunku prywatyzacji i liberalizacji. Twórcą chilijskiej reformy emerytalnej był Jose Pinera, minister w rządzie Pinocheta, związany z nieliberalną szkołą chicagowską. W zarządach firm zarządzających prywatnymi funduszami emerytalnymi znaleźli się głównie członkowie rządu Pinocheta ${ }^{2}$. Reforma została oparta na ideologicznych argumentach mających dowodzić wyższości systemu emerytalnego opartego na własności prywatnej i indywidualnej odpowiedzialności nad systemem solidarności międzypokoleniowej ${ }^{3}$.

W $1981 \mathrm{r}$. junta Pinocheta wywróciła system repartycyjny. Zastąpiła go w całości prywatnymi funduszami emerytalnymi (w Chile mają one skrót AFP - Administración de Fondos de Pensiones). To znaczy, że powstał praktycznie jednofilarowy system emerytalny oparty prawie wyłącznie o AFP. Pozostałe 2 filary mają znacznie mniejsze znaczenie. Pracujący mieli wpłacać składki na indywidualne konta emerytalne, fundusze miały obracać ich pieniędzmi i pobierać marże. Wszyscy młodzi, którzy wchodzili na rynek pracy, zostali ex lege członkami AFP, a ci, którzy do chwili prywatyzacji systemu wpłacali składki na państwowe emerytury, teoretycznie mogli wybrać: zostać w starym systemie albo przejść do nowego. Ale w praktyce odmowa przejścia do AFP groziła utratą pracy i jedynymi grupami zawodowymi, którym zezwolono na pozostanie w publicznym systemie emerytalnym były służby mundurowe.

Rewolucja w emeryturach była dla jej twórców - Chicago Boys, uczniów ultraliberalnego ekonomisty i ideologa Miltona Friedmana - jednym z filarów eksperymentu społeczno-gospodarczego, jaki przeprowadzali w Chile. Gospodarka miała uwolnić się od regulacji państwowych, państwo miało ograniczyć się do roli nocnego stróża. Dekalog Chicago Boys nakazywał prywatyzować, liberalizować ceny i handel, uelastycznić prawo pracy. Drastycznie ograniczono prawo tworzenia związków zawodowych, a strajki solidarnościowe, nie mówiąc o strajku generalnym, są w Chile do dziś nielegalne. Model ten opisywano nieraz jako gospodarkę kasyna: przegrywają wszyscy z wyjątkiem garstki uprzywilejowanych i szczęśliwców.

\footnotetext{
${ }^{2}$ M. Riesco, 25 Years Reveal Myths of Privatized Federal Pensions in Chile, 10.03.2015, [w:] L. Orędziak, OFE katastrofa prywatyzacji emerytur w Polsce, Instytut Wydawniczy Książka i Prasa 2014.

${ }^{3}$ L. Orędziak, op. cit., s. 143.
} 
Moim zdaniem, idea liberalizmu Augusta Pinocheta był swoistą wymówką wobec społeczeństwa. Jeśli wszystkie przedsiębiorstwa zostaną sprywatyzowane a podatki obniżone, to obywatele nie będą już uprawnieni do jakichkolwiek roszczeń względem państwa i władza uwolni się od obowiązków społecznych. Prywatne fundusze emerytalne miały stać się integralną częścią tej społecznej inżynierii.

Przechodząc do omówienia konkretnych regulacji, charakterystyczna dla tego systemu jest niska składka emerytalna w wysokości $10 \%$ wynagrodzenia brutto. Całość składki wpływa do filaru kapitałowego. Ubezpieczony wybiera jedno z AFP oraz sposób inwestowania swoich pieniędzy spośród 5 subfunduszy A - E, gdzie A oznacza metodę najbardziej ryzykowną, lecz mogącą dać potencjalnie największy zysk ${ }^{4}$.

Uzyskanie emerytury w Chile jest uzależnione tylko od warunku osiągnięcia wieku emerytalnego, który wynosi 60 lat dla kobiet i 65 lat dla mężczyzn. Ubezpieczony, który spełnił tę przesłankę może rozpocząć pobieranie świadczenia w dowolnym momencie, kontynuując swoją aktywność zawodową i odprowadzanie składek. Dla uzyskania prawa do emerytury nie jest wymagane rozwiązanie stosunku pracy, ani zaprzestanie innej formy zarobkowania.

Istnieją 4 rodzaje świadczenia emerytalnego i sposoby jego uzyskiwania. Po pierwsze, wypłata całej sumy po osiągnięciu wieku emerytalnego. Po drugie, uzyskanie z całości zgromadzonej sumy dożywotniej emerytury wypłacanej co miesiąc w jednakowej wysokości. Po trzecie, z części zgromadzonych pieniędzy uzyskiwanie comiesięcznej renty od funduszu inwestycyjnego w określonej w umowie wysokości i do określonego momentu, a później uzyskiwanie z pozostałej części pieniędzy normalnego świadczenia emerytalnego. Po czwarte, wypłata części pieniędzy i uzyskanie świadczenia emerytalnego z drugiej. Mnogość opcji jest przywilejem i wyrazem liberalizmu, jednak być może zbyt daleko posuniętego przy wyborze pierwszej z nich, bo może poskutkować w przypadku przetracenia oszczędności pozostaniem emeryta bez środków do życia.

W interesujący sposób rozwiązano kwestię wcześniejszych emerytur. Każdy ubezpieczony może przejść na wcześniejszą emeryturę niezależnie od wieku i stażu pracy, jeśli zgromadził wystarczająco funduszy by stopa zastąpienia (tu jest to proporcja wysokości emerytury do średnich zarobków z ostatnich 10 lat) jego świadczenia emerytalnego wyniosła $80 \%$ a wysokość przyszłego świadczenia emerytalnego przewyższała określoną ustawowo kwotę. Dzięki temu pozwala się skończyć pracę osobom, które mądrze oszczędzały i inwestowały swoje pieniądze. Przy tym nie dopuszcza się sytuacji, w której emerytura

\footnotetext{
${ }^{4}$ A. M. Shelton, Chile's Pension System: Background in Brief, Analyst in Income Security, 28 marca 2012 roku (dostęp: 16.11.2017), http://www.google.pl/url?sa=t\&rcct=j\&q=chile\%E642\%80\%$99 \mathrm{~s} \% 20$ pension $\% 20$ system...
} 
byłaby nieproporcjonalnie niska do wcześniejszego poziomu życia ubezpieczonego.

Profesorowie John B. Williamson oraz Fred C. Pampel charakteryzując w 1998 r. reformę emerytalną w Chile zwrócili uwagę na następujące kwestie. Stosunkowo wysokie stopy zwrotu występujące w chilijskich funduszach emerytalnych wynikły w dużej części ze specyficznych okoliczności, jak wysokie oprocentowanie obligacji rządowych $\mathrm{w}$ latach 80 . wynikające $\mathrm{z}$ trwającego wówczas w Ameryce Łacińskiej kryzysu zadłużenia. W wyniku reformy, emerytury co najmniej połowy pracowników należących do funduszy spadną do poziomu poniżej 50\% ostatniego wynagrodzenia i będą stanowić mniej niż poziom zapewniający minimum egzystencji. Rozpowszechnione jest zjawisko uciekania w szarą strefę pracowników o niskich płacach po to, by uniknąć płacenia składek emerytalnych i mieć wyższy dochód do dyspozycji5. Przez długi okres niemal całość aktywów chilijskich funduszy emerytalnych stanowiły krajowe skarbowe papiery dłużne oraz gwarantowane przez rząd depozyty bankowe. To właśnie wysokie stopy procentowe w Chile, a nie efektywność zarządzania funduszami emerytalnymi, decydowały przez wiele lat o stopach zwrotu osiąganych przez te fundusze ${ }^{6}$.

Oceniając efekty funkcjonowania funduszy zarządzanych przez AFP profesor Manuel Riesco w 2010 r. wskazał, że w okresie od 1981-2008 obowiązkowe składki wpłacone przez członków AFP do tych funduszy wyniosły 59 mld dolarów (co stanowiło 1/3 PKB Chile w 2008 r.), z tego AFP oraz powiązane $\mathrm{z}$ nimi $\mathrm{w}$ ramach grup finansowych towarzystwa ubezpieczenie pobrały sobie 19,9 mld dolarów jako opłaty i prowizje. Oznaczało to w praktyce, że aż 1 z 3 dolarów przekazanych pod przymusem państwowym do prywatnych funduszy został przechwycony przez te instytucje finansowe. Druga wielką grupą beneficjentów systemu AFP okazały się podmioty, w których fundusze te inwestowały środki pochodzące ze składek emerytalnych. Od początku istnienia funduszy do końca 2008 r. wielkie korporacje działające w Chile otrzymały 47\% środków zarządzanych prez AFP, przy czym połowa $\mathrm{z}$ tego trafiła do grupy 12 korporacji, $\mathrm{w}$ tym do firm powiązanych z AFP, a $28,5 \%$ zostało zainwestowane za granicą, $\mathrm{z}$ czego połowę $\mathrm{w}$ niewielkiej grupie 8 międzynarodowych funduszy inwestycyjnych. Na skutek kryzysu finansowego w 2008 r. zyski wypracowane w wyniku inwestowania składek spadły o 24,7 mld dolarów, co stanowiło $60 \%$ całości zysków osiągniętych do końca 2007 r. Oznacza to, że w ciągu tylko jednego roku AFP straciły $60 \%$ zysków zakumulowanych w ciągu poprzednich 26 lat. Konieczne okazało się zapewnienie przez państwo minimalnych świadczeń dla 2/3 członków funduszy AFP, ponieważ w funduszach tych nie zdołali oni zebrać

\footnotetext{
${ }^{5}$ J.B. Williamson, F.C. Pampel, Does the privatization of social security make sense for developing nations?, International Social Security Reviwe, Vol. 51, No. 4/1998, [w:] L. Orędziak, op. cit.

${ }^{6}$ N. Barr, P. Diamond, Pension Reform. A Short Guide, [w:] L. Orędziak., op. cit.
} 
środków wystarczających nawet na minimalną emeryturę. Z kolei emerytury tych, którzy zdołali uzyskać je z funduszy AFP są o połowę niższe od tych, jakie przysługiwałyby z systemu emerytalnego obowiązującego przed reformą ${ }^{7}$.

Proces wycofywania się z kapitałowego systemu emerytalnego rozpoczął się w 2008 r., gdy z powodu kryzysu finansowego doszło do krachu na chilijskiej giełdzie, który bezpośrednie przełożył się na uszczuplenie gromadzonych przez lata środków ubezpieczonych. Warto w tym miejscu przytoczyć zapewnienia rządu z początku lat 80 ., iż emerytura uzyskana w kapitałowym systemie emerytalnym wyniesie $70 \%$ średniej pensji z ostatnich pięciu lat. Ta obietnica okazała się jednak płonna, gdyż wysokość świadczeń osób kończących swoją aktywność zawodową w 2010 r. kształtowała się na poziomie około $30 \%$ ich przeciętnego wynagrodzenia $\mathrm{z}$ ostatnich pięciu lat.

Na głodową wysokość emerytur wpływ miały również drakońskie opłaty pobierane przez AFP. Jako że były one limitowane jedynie przez ,wolną konkurencję", to dochodziły one nawet do kilkudziesięciu procent.

Na początku lat 80 . funkcjonowały 22 fundusze emerytalne. Obecnie zaledwie 6, przez co rynek AFP, na którym miała panować konkurencja, z wolnego rynku zmienił się w oligopol, czyli model rynku, na którym występuje niewielka liczba - od dwóch (duopol) do kilkunastu producentów, których decyzje cenowe są wzajemnie uzależnione, a uzależnienie to przyjmuje najczęściej formę paralelizmu cenowego. W mojej ocenie, rynek AFP w Chile w swym dotychczasowym kształcie nosił znamiona oligopolu, przez co wzięcie pojęcia „wolna konkurencja" w cudzysłów uważam za zasadne.

Ze względu na powyższe okoliczności w 2008 r. zaczął się szeroki proces reform chilijskiego systemu emerytalnego. Przede wszystkim wzmocniono, mający wcześniej marginalne znaczenie, tzw. zerowy filar systemu emerytalnego (nazewnictwo zaczerpnięte z nomenklatury Banku Światowego), finansowany w całości z podatków ogólnych. Oferuje on 2 rodzaje świadczeń - emeryturę podstawową (minimalną) określaną jako świadczenie zapobiegające ubóstwu, które istniało od początku wprowadzania reformy. A także, ustanowione dopiero w 2008 r., świadczenie uzupełniające emeryturę kapitałową tzw. solidarnościowe uzupełnienie emerytury. Przesłanki formalne ich nabycia są identyczne: co najmniej 20 lat zamieszkania w Chile, z czego co najmniej 4 lata pobytu w kraju powinny przypadać w okresie ostatnich pięciu lat poprzedzających wniosek.

Emerytura minimalna ma wartość stałą, która wynosi około 500 zł miesięcznie. Jej cechą charakterystyczną jest brak zależności pomiędzy uiszczaną składką a uzyskiwanym świadczeniem. W zamyśle jego twórców, opierających się na nurcie ekonomicznego liberalizmu, miała on być przeznaczona dla wą-

\footnotetext{
${ }^{7} \mathrm{M}$. Riesco, Resultados para sus Afilados de las AFP u Companias de Seguros Relacionadas con la Prevision 1982-2009, marzec 2010, [w:] L. Orędziak, op. cit.
} 
skiej grupy ubezpieczonych, którzy ze względu na swą niepracowitość, nie uzyskali odpowiednio wysokiej emerytury z filaru kapitałowego, która przewyższałaby świadczenie minimalne gwarantowane przez filar zerowy państwowego systemu emerytalnego. Jednak rzeczywistość okazała się odmienna, bowiem odsetek emerytów korzystających z dobrodziejstw publicznego systemu emerytalnego przekroczyła wielokrotnie założenia reformatorów. Emerytura podstawowa skierowana jest do osób, które uzyskały krótki staż pracy albo nie pracowały wcale.

Nowowprowadzonym świadczeniem jest solidarnościowe uzupełnienie emerytury. Uprawnionymi do niego są ubezpieczeni, którzy przeszli pozytywnie test majętności (ich emerytury nie zawierają się w grupie 40\% najwyższych świadczeń) i odprowadzali składki do drugiego filaru, jednak nie uzbierali na swoim koncie kwoty, pozwalającej na uzyskanie emerytury w określonej wysokości. W praktyce osoby korzystające ze świadczenia uzupełniającego uzyskują emerytury nieznacznie wyższe od minimalnych - w przedziale około 600-900 zł. W tym wypadku świadczenie jest po części powiązane z odprowadzonymi składkami według zasady, że każde peso zgromadzone na koncie emerytalnym powiększa emeryturę, ale nie o całe peso. Adresatami tego świadczenia są ubezpieczeni, którzy odprowadzali składki przez okres swojej aktywności zawodowej, lecz mimo tego zgromadzone w AFP środki okazały się niewystarczające.

Obecnie państwo za pośrednictwem filaru zerowego opłaca w całości lub dopłaca do 75\% wszystkich emerytur. W 2012 r. rząd wydał 2 razy więcej na wypłatę emerytur niż prywatne fundusze. Biorąc pod uwagę wyższe niż polskie ceny występujące w górzystym południowoamerykańskim kraju, emerytura podstawowa oraz solidarnościowa są świadczeniami poniżej minimum egzystencji. Oznacza to, że chilijski system emerytalny dla tej grupy osób nie spełnił swojego podstawowego celu, czyli nie zapewnił ubezpieczenia od niezdolności do pracy z powodu ryzyka starości. Emeryci uzyskujący świadczenie minimalne i solidarnościowe zmuszeni są pracować.

Rozumiejąc negatywne skutki wysokich kosztów administracyjnych funkcjonowania funduszy emerytalnych, w trakcie reformy z 2008 r. stworzono interesujący mechanizm konkursu opłat. Do AFP, które zadeklarowało najniższe opłaty na rynku, w nagrodę dopisywano automatycznie wszystkich ubezpieczonych, rozpoczynających gromadzenie kapitału, którzy sami nie wybrali swojego AFP. Zastąpiło to wcześniej obowiązującą procedurę losowania funduszu.

Innymi zmianami było: zwiększenie kontroli nad AFP poprzez ustanowienie obligatoryjnego oraz niezależnego członka rady nadzorczej dla każdego z funduszy, zezwolenie AFP na inwestowanie do 80\% środków za granicą. Dodatkowo przeznaczono środki na edukację ekonomiczną społeczeństwa np. pokazując, iż najważniejsze są składki odprowadzone za młodu, ponieważ przynoszą one największe odsetki ze względu na długi okres ich inwestycji. 
Dla pełnego obrazu chilijskiego systemu emerytalnego, warto wskazać, że istnieje również mało popularny dobrowolny filar kapitałowy. Ubezpieczeni mogą nadpłacać składkę do AFP ponad jej obligatoryjną wysokość, w ramach tego samego funduszu, do którego wpływa obowiązkowa część ich składki emerytalnej. Niewielkie znaczenie tego filaru wynika z braku zaufania społeczeństwa do funduszy emerytalnych przede wszystkim ze względu na wysokie opłaty przez nie pobierane.

Poza już wprowadzonymi reformami, obecna Prezydent Michelle Bachelet przedstawiła projekt utworzenia publicznego inwestycyjnego funduszu emerytalnego, zwanego państwowym AFP. Miałby on dołączyć do sześciu istniejących już funduszy emerytalnych i z nimi konkurować. Powstałby w sposób nietypowy podmiot, będący swego rodzaju publicznym OFE. Zdaje się, że jest to specyficzna metoda na demontaż reformy emerytalnej z 1981, gdyż prawdopodobnie większa część ubezpieczonych, zawiedzionych prywatnymi funduszami inwestycyjnymi, hipotetycznie wybrałaby właśnie nowo utworzony publiczny fundusz emerytalny, przenosząc ostatecznie odpowiedzialność za wypłatę świadczenia emerytalnego z powrotem na państwo.

Reasumując, cechami charakterystycznymi dla chilijskiego filaru kapitałowego są: odprowadzanie całości składki emerytalnej do niego, niska składka emerytalna w ujęciu ogólnym - 10\%, lecz wysoka, z perspektywy składki odprowadzanej do funduszy emerytalnych, obligatoryjność uczestnictwa w kapitałowym filarze emerytalnym, będącym co do zasady jedynym elementem systemu emerytalnego, istnienie w ramach wyjątku filaru zerowego zapewniającego minimalne świadczenie oraz szczątkowego filaru dobrowolnego, również opartego o AFP, występowanie mechanizmu konkursu opłat, niewielka ilość AFP na rynku. Wycofywanie się prekursora wprowadzenia kapitałowego systemu emerytalnego ze swojej idei, u którego omawiane rozwiązania istniały najdłużej, stanowi wyraźny znak, iż stworzona struktura ma poważne wady.

Na marginesie warto wskazać, że, na podstawie analizy licznych publikacji, zauważalny jest trend, iż największymi zwolennikami chilijskiego systemu emerytalnego są obcokrajowcy. Podczas gdy zdecydowana większość chilijskich naukowców oraz dziennikarzy odnosi się do kapitałowego systemu emerytalnego krytycznie.

\section{Węgry}

Węgrzy w 1998 r., podobnie jak rok później Polacy, wprowadzili do swojego systemu emerytalnego obligatoryjny filar kapitałowy. Początkowo odprowadzano do niego $6 \%$ składki emerytalnej, by ostatecznie podnieść tę wartość do $8 \%$. Tak powstały mieszany system emerytalny różnił się jednak znacznie od polskiego, gdyż pierwszy, dominujący filar, opierał się na systemie zdefi- 
niowanego świadczenia a nie zdefiniowanej składki. Opłacanie składki było podzielone $\mathrm{w}$ ten sposób, że pracodawca był zobowiązany do odprowadzania $22 \%$ wynagrodzenia na I repartycyjny filar. $Z$ kolei pracownik obligatoryjnie uiszczał $8 \%$ pensji na II filar.

W tym kraju wszyscy dotychczasowi uczestnicy systemu emerytalnego mogli wybrać pomiędzy systemem repartycyjnym a mieszanym. Natomiast osoby wchodzące na rynek pracy, czyli rozpoczynające aktywność zawodową po 30 czerwca 1998 r. były przypisywane ex lege do systemu repartycyjno-kapitałowego. Na zostanie członkiem funduszu emerytalnego ubezpieczeni decydowali się tym chętniej, im byli oni młodsi. Zależność między wiekiem a wybieraniem uczestnictwa w funduszach emerytalnych była prawie wprost proporcjonalna.

Oprócz grupy stanowiącej 25\% zatrudnionych, których dotyczył obowiązek przystąpienia do tego filara, przystąpiło do niego dobrowolnie kolejne 50\% zatrudnionych. Ogromne początkowo poparcie dla prywatnych funduszy emerytalnych uległo jednak znacznej erozji na skutek słabych wyników przez nie osiąganych. Z danych opublikowanych w marcu 2011 r. wynikało, że w ciągu 13 lat istnienia funduszy średnia stopa zwrotu $z$ inwestowania powierzonych im składek emerytalnych była niższa od stopy inflacji w tym okresie ${ }^{8}$.

Węgierski obligatoryjny filar kapitałowy można scharakteryzować następująco. Na koniec 2010 r. funkcjonowało w nim 18 funduszy emerytalnych, przy czym 5 największych funduszy skupiało aż 74,7\% ogólnej liczby wszystkich członków oraz $82,1 \%$ wartości zgromadzonych aktywów. W początkowych latach funkcjonowania drugiego filara ponad $80 \%$ aktywów funduszy lokowano w obligacje skarbowe; mimo że ten odsetek zmniejszał się stopniowo (74\% w 2004 r., 58\% w 2007 r., 54\% w 2008 r.), to i tak pozostał wysoki (48\% w 2009 r.). Średnie opłaty pobierane rocznie przez towarzystwa emerytalne kształtowały się na poziomie od 6,45\% w 2002 r. do 5,04\% w 2009 r. W ciągu 12 lat istnienia prywatne fundusze emerytalne $\mathrm{w}$ ramach obowiązkowego filara kapitałowego funkcjonowały znacznie gorzej niż oczekiwano w momencie ich tworzenia, nawet gdyby nie było kryzysu finansowego'.

W październiku 2008 r. MFW, Bank Światowy i Unia Europejska udzieliły Węgrom pożyczki w wysokości 20 mld dolarów. Do głównych działań dotyczących systemu emerytalnego podjętych w tym kraju w 2009 r. w celu stabilizowania finansów publicznych należy zaliczyć: stopniowe podwyższenie wieku emerytalnego z 62 do 65 lat w okresie od 2014 do 2022, wyeliminowa-

\footnotetext{
${ }^{8}$ Changes in the Hungarian pension system i 2010-2011, 15.09.2011, International Social Security Association, [w:] L. Orędziak, op. cit.

${ }^{9} \mathrm{~K}$. Hirose, Hungary, CANPI-ONYF - Information on the major benefit regulations and organizational structure of the pension insurance system in Hungary, Central Administration of National Pension Insurance, sierpień 2012, http://www.onyf.hu/en/?module-news\&onyf_en_left_kozlemenyek\&root=ONYF (dostęp: 16.11.2017).
} 
nie trzynastej emerytury, zmiany w systemie waloryzacji emerytur, zamrożenie emerytury minimalnej, przesunięcie waloryzacji emerytur z 2009 r. na 2010 r., ograniczenie możliwości przechodzenia na wcześniejsze emerytury ${ }^{10}$.

W 2009 r. podniesiono składki na ubezpieczenie emerytalne: po stronie pracodawcy z $22 \%$ do $24 \%$ podstawy wymiaru oraz pracowników z $8 \%$ do $9 \%$ podstawy wymiaru, czego celem było zwiększenie wpływów do I i II filaru i odciążenie dotacji z budżetu państwa. Krytycy tej zmiany mówili o spowodowanym w jej wyniku wzroście kosztów pracy i obniżeniu konkurencyjności gospodarki, co spowodowało pogłębienie recesji Węgier. Moim zdaniem należy im przyznać rację, gdyż ustanowienie obowiązkowej składki emerytalnej na poziomie $33 \%$ wynagrodzenia raczej wpisuje się w model gospodarki socjalistycznej niż wolnorynkowej.

Dekonstrukcja filara kapitałowego jest również konsekwencją światowego kryzysu gospodarczego, którego skutki odczuwane są zarówno w sferze finansów publicznych jak i w polityce społecznej państwa. Wśród uwarunkowań zmian systemu kluczową wydaje się zmiana polityczna dokonana na Węgrzech w 2010 roku, czyli dojście do władzy centro-prawicowej partii Fidesz na czele z Victorem Orbanem. Rząd Orbana wygrał wybory na fali sprzeciwu wobec rządów lewicy, która wprowadziła wiele zmian socjalnych (np. trzynaste emerytury) oraz w wyniku nadmiernego zadłużenia finansów publicznych (węgierski dług publiczny w 2010 r. przekroczył 85\% PKB), które doprowadziło do spadku wiarygodności węgierskiej gospodarki i niepokojów społecznych.

W 2010 r. parlament węgierski uchwalił kolejne ustawy. Ustawą nr 100 zniesiono obowiązek przystąpienia do drugiego filara przez osoby rozpoczynające aktywność zawodową. Ustawą nr 101 zawieszono na 14 miesięcy przekazywanie składek do funduszy emerytalnych (w okresie między 1 listopada 2010 r. a 31 grudnia 2011 r.), oznaczające pozostawienie w tym okresie całej składki emerytalnej w państwowym systemie emerytalnym. Ustawą nr 154 ustanowiono automatyczny transfer wszystkich środków zgromadzonych na rachunkach członków funduszy emerytalnych do budżetu państwa, o ile członek funduszu nie złoży specjalnego oświadczenia, że chce pozostać w funduszu ${ }^{11}$.

Nie zdecydowano się na obniżenie świadczeń, ale zamrożono ich wysokość, co nie budziło społecznego sprzeciwu. Zakres podmiotowy ustawy podnoszącej wiek emerytalny obejmuje pracujących i pracujących na własny rachunek, oprócz urzędników i sędziów. Zachowany został sposób naliczania wysokości świadczenia a minimalna emerytura została ustalona na 28 tysięcy forintów, czyli około 450 zł miesięcznie.

\footnotetext{
${ }^{10} \mathrm{~K}$. Hirose, Results of the survey on Eurpean pension system, 15.03.2012, Committee on Social Affairs, Health and Sustainadble Development, Parliamentary Assembly, Council of Europe 2012, s. 27, [w:] L. Orędziak, op. cit.

${ }^{11}$ Ibidem.
} 
Na początku listopada 2010 r. parlament węgierski dał Węgrom czas do 31 stycznia 2011 roku na decyzję, czy chcą pozostać w kapitałowym systemie emerytalnym, do czego konieczne było złożenie odpowiedniego oświadczenia. Tylko niewiele ponad 100 tys. osób (3,3\% uprawnionych) postanowiło pozostać w prywatnych funduszach emerytalnych. Co ciekawe, według ustawy ubezpieczeni, którzy zdecydowali się pozostać w filarze kapitałowym tracili jakiekolwiek uprawnienia do emerytury z pierwszego filara, zatem całość świadczenia miałaby zależeć wyłącznie od wyników funduszu emerytalnego ${ }^{12}$. Tak rygorystyczna regulacja przyczyniła się do prawie jednogłośnego wyboru powrotu do systemu repartycyjnego przez Węgrów.

Dopiero późniejszy wyrok Trybunału Konstytucyjnego uznał powyższą regulację za niezgodną z Konstytucją, stwierdzając iż ci, którzy zdecydowali się na pozostanie w II filarze nie mogą zostać pozbawieni repartycyjnej części emerytury. Jednak, nawet pomimo tego orzeczenia, skarżony przepis spełnił swój cel propagandowy, skutecznie zniechęcając obywateli do uczestnictwa w funduszach emerytalnych. Z 40 miliardów złotych zgromadzonych w II filarze węgierskiego systemu emerytalnego po transferze środków pozostało zaledwie około 1,3 mld złotych.

Tak silne osłabienie węgierskich funduszy emerytalnych doprowadziło do upadłości lub wycofania się wszystkich działających do tej pory funduszy emerytalnych. Jednocześnie żadna inna zagraniczna instytucja finansowa nie zdecydowała się wejść na rynek węgierski, który z powodu działań rządu stał się nieprzyjazny dla inwestycji.

Warto zauważyć, że rząd węgierski, w przeciwieństwie do polskiego, zdecydował, że osobom, które złożą deklarację w sprawie pozostania w drugim filarze wszystkie zgromadzone dotąd środki zostaną pozostawione w funduszu. Odmiennie niż polski ustawodawca, który przeniesieniem części środków ulokowanych w obligacjach objął wszystkich członków OFE, niezależnie od ich woli kontynuowania członkostwa.

W kontekście dyskusji o demontażu II filaru systemu emerytalnego w Polsce warto przyjrzeć się niedawnemu orzeczeniu Europejskiego Trybunału Praw Człowieka z 15 stycznia 2013 r. w sprawie „E.B. przeciwko Węgrom” (sygn. akt 34929/11). Wyrok ten wymaga bliższej analizy. U podstaw orzeczenia leżała reforma węgierskiego systemu ubezpieczeń, która doprowadziła do praktycznej likwidacji prywatnych funduszy emerytalnych. Istotne z punktu widzenia polskiej reformy, było stworzenie mechanizmu domyślnego przejścia z systemu prywatnego do państwowego: członkowie prywatnych funduszy zostali zobowiązani do złożenia w krótkim terminie deklaracji o pozostaniu w funduszach

\footnotetext{
${ }^{12}$ A. Ferensztajn, Wegierski minister gospodarki: ZUS albo nic, [w:] „Forbes”, 26.11.2010, https://www.forbes.pl/wiadomosci/wegry-likwiduja-drugi-filar/n4nz36y (dostęp: 16.11.2017).
} 
prywatnych (tzw. opt-out z reformy), w przeciwnym wypadku następował automatyczny transfer do systemu państwowego. Wyrokując w sprawie „E.B. przeciwko Węgrom" ETPC nie dopatrzył się naruszenia praw zagwarantowanych w art. 1 Protokołu nr 1 do EKPC. Ale ETPC nie badał w swym orzeczeniu sytuacji prawnej osób, które zostały przyporządkowane do państwowego systemu emerytalnego - skarżąca należała bowiem do niewielkiej grupy osób (mniej niż $2 \%$ ubezpieczonych), którzy zadeklarowali zamiar pozostania w prywatnym funduszu. Rozwiązanie węgierskie tym różni się od propozycji sformułowanych przez polski rząd, że ostatecznie nie przewiduje nacjonalizacji środków wobec tych osób, które zdecydowały się na pozostanie w systemie funduszy prywatnych ${ }^{13}$.

Po reformie węgierski system emerytalny z systemu mieszanego stał się ponownie systemem repartycyjnym. nawet pomimo wysokiej składki wpływającej do I filaru - 22\% następnie podwyższonej do $24 \%$ - rząd nie mógł sobie pozwolić na dalsze finansowanie funduszy emerytalnych, kosztem powiększającego się dhugu publicznego. Uzasadniona wydaje się konkluzja, że niezależnie od wysokości składek i podatków, w sytuacji istnienia obligatoryjnego filaru kapitałowego, w którym gromadzone są realne środki, dla rządzących zawsze będzie istnieć pokusa transferu tych środków, przez co bezpieczeństwo aktywów akumulowanych w obowiązkowym filarze kapitałowym jest, ze względów politycznych - wątpliwe.

\section{Podsumowanie}

Kapitałowe reformy emerytalne w Chile i na Węgrzech okazały się porażką. Z czterech celów, jakie miały spełnić, z pewnością nie udało im się osiągnąć dwóch. Mianowicie, ubezpieczeni będący członkami funduszy emerytalnych uzyskali niższe świadczenia niż osoby, które pozostały wyłącznie w publicznym filarze emerytalnym. Dodatkowo budżety tych państw zamiast uodpornić się na kryzys zadłużeniowy spowodowany przewidywanym załamaniem demograficznym, wpadły w pętle długu publicznego znacznie szybciej i silniej niż gdyby uniknięto liberalnych reform emerytalnych. Sukcesem zakończyło się silniejsze uzależnienie wysokości świadczenia od odprowadzanych przez okres aktywności zawodowej składek, jednak ten postulat mógłby zostać osiągnięty z pominięciem utworzenia kapitałowego filaru emerytalnego. Głębszych badań wymaga udzielenie odpowiedzi na pytanie, czy fundusze emerytalne przyczyniły się do wzrostu gospodarczego. $Z$ jednej strony umożliwiły one spółkom akcyjnym łatwiejszy dostęp do kapitału. $Z$ drugiej, przyczyniły się do utworze-

\footnotetext{
${ }^{13}$ A. Radwan, R. Mężyk, Likwidacja OFE: kazus węgierski a prywatny system emerytalny, Rzeczpospolita, 12.09.2013, http://www.rp.pl/artykul/1047104-Likwidacja-OFE--kazus-wegierski-a-prywatny-system-emerytalny.html\#ap-1 (dostęp: 16.11.2017).
} 
nia bańki spekulacyjnej na giełdzie i przewartościowania papierów wartościowych. Należy w takim razie zastanowić się, czy gdyby nie szeroki dopływ środków na giełdy spowodowany aktywnością kapitałowych filarów emerytalnych, spadki na giełdzie i kryzys finansowy byłyby łagodniejsze? Z pewnością filary kapitałowe systemów emerytalnych nie pozwoliły na uniknięcie, czy choćby złagodzenie, kryzysów gospodarczych, które w Chile i na Węgrzech były poważne.

Warto zauważyć, że próbując rozwiązać spór, który system emerytalny-repartycyjny, czy kapitałowy, jest efektywniejszy, duże znaczenie będzie miała odpowiedź na pytanie, czy zwrot netto z inwestycji prowadzonych przez fundusze, czyli po odliczeniu kosztów, przekracza wzrost wynagrodzeń lub inflację, od których uzależniona jest indeksacja środków w systemie publicznym? W przypadku Węgier i Chile odpowiedź na to pytanie jest negatywna.

Abstrahując od tych rozważań, konieczna wydaje się analiza przyczyn porażki funduszy emerytalnych. Czy tkwi ona w samej istocie ich idei, czy też może wywołana ona została niedopracowaniem reform, spowodowanych nadmierną wiarą w liberalizm ekonomiczny, skutkującą niedostatkiem regulacji?

Moim zdaniem niezasadne byłoby całkowite wycofanie się z koncepcji funduszy emerytalnych. Wymaga ona po prostu znacznego dopracowania, ostrożności i położenia większego nacisku na prawa i pozycję ubezpieczonych, kosztem osłabienia funduszy. Konkretyzując powyższe wnioski, uważam że największym błędem było nieuregulowanie, na poziomie ustawowym, wysokości opłat pobieranych przez fundusze emerytalne, pozostawiając je „niewidzialnej ręce rynku", co najlepiej oddaje przykład Chile, gdzie AFP pobierały nawet kilkadziesiąt procent wpływającej składki. Opłaty pobierane przez fundusze powinny być od początku limitowane do umiarkowanego poziomu - na przykład takiego, jaki wprowadziła od lutego 2014 r. Polska, czyli 1,75\% opłaty od odprowadzonej składki. Warto zauważyć, że po wprowadzeniu tego surowego limitu opłat żadne OFE nie wycofało się z polskiego rynku, godząc się na kontynuowanie swojej działalności w taki sam jak dotychczas sposób, oferując te same usługi, jednak pobierając za nie znacznie mniejsze koszty, co może zaowocować wyłącznie korzyściami dla ubezpieczonych.

Należy jednak zwrócić uwagę na okoliczność, iż twórcy reform, wprowadzających kapitałowe systemy emerytalne, będący zwolennikami niewidzialnej ręki rynku, nie zauważyli z góry narzuconej dysproporcji w stosunkach fundusze - ubezpieczeni. Zgodnie z tezą liberałów, konkurencja i nieograniczona wolność dokonywania transakcji przez uczestników rynku powinny doprowadzić do stanu równowagi rynkowej, w którym obie strony transakcji - kupujący i sprzedający, będą zadowoleni a cena towaru odpowiednia. Jednak liberałowie nie stworzyli wolnego rynku funduszy oraz ich klientów, ze względu na przymus członkostwa. W Chile, Polsce oraz na Węgrzech znaczna część ubezpieczonych musiała obligatoryjnie zostać klientami funduszu emerytalnego. 
W mojej ocenie, stało to w sprzeczności z zasadami wolnego rynku, ponieważ uprzywilejowywało ex lege fundusze emerytalne. Nie można mówić o wolnej konkurencji, jeśli klient jest zmuszany przez państwo do nabycia danej usługi. Tym bardziej, gdy grono je świadczących jest stosunkowo nieliczne (6 funduszy w Chile), co może nosić znamiona oligopolu. W takiej sytuacji nie należy się dziwić, iż niewprowadzenie limitu opłat pobieranych przez fundusze poskutkowało wyzyskiem ubezpieczonych. Być może koszty administracyjne byłyby niższe i rzeczywiście nie wymagały interwencji ustawodawcy, gdyby wszyscy ubezpieczeni mieli od początku możliwość nieprzystąpienia do kapitałowego filaru emerytalnego oraz wycofania się z niego w każdym momencie.

Zdaniem większości ortodoksyjnych ekspertów równowaga w systemie repartycyjnym jest możliwa tylko wtedy, gdy liczebność pokoleń jest w miarę równa, a w przypadku demograficznego załamania równowaga finansowa całego systemu staje pod znakiem zapytania. Jednakże całe to rozumowanie jest błędne, gdyż zakłada a priori niezmienną wydajność pracy, ale gdy owa wydajność rośnie, (co jest niepodważalnym faktem), to większy dochód jest generowany przez mniejszą ilość pracowników. Przez co repartycyjny filar kapitałowy, oferujący dopasowane do czynników gospodarczo-demograficznych świadczenia, może okazać się stabilniejszy od narażanego na wahania giełdowe filaru kapitałowego. Bowiem wprowadzenie funduszy emerytalnych na Węgrzech oraz w Chile zakończyło się przede wszystkim działaniami, mającymi na celu złagodzenie lub wręcz odwrócenie skutków reformy.

Poza tym analiza przykładu Chile może posłużyć jako odpowiedź dla zwolenników obniżenia składki emerytalnej, która miałaby doprowadzić do tego, iż obywatele sami we własnym zakresie zadbają o zabezpieczenie się przed niezdolnością do pracy z powodu starości. Wprowadzenie niskiej składki emerytalnej na poziomie $10 \%$ miało wpływ na uzyskanie głodowych świadczeń z systemu emerytalnego. Z kolei, wbrew założeniom, większość obywateli, osiągając wiek emerytalny nie miało żadnych oszczędności, przez co ostatecznie państwo było zobowiązane do poniesienia ciężaru ich utrzymania, tworząc zerowy filar emerytalny. $Z$ tym, że musiało go finansować z podatków ogólnych, gdyż całość składki emerytalnej była przekazywana do funduszy. Powyższe przekłada się jednoznacznie na negatywną oceną propozycji ekonomistów z Centrum Adama Smitha, żeby obniżyć składkę emerytalną. Jak pokazuje doświadczenie, ubezpieczeni nieobarczeni przymusem odkładania środków na zabezpieczenie starości w większości tego nie robią, przez co ostatecznie i tak państwo zmuszone jest zadbać o ich utrzymanie. Także interpretacja znikomych oszczędności Polaków na Indywidualnych Kontach Emerytalnych oraz Indywidualnych Kontach Zabezpieczenia Emerytalnego wskazuje na słuszność tezy, iż gromadzenie środków na emeryturę powinno należeć przede wszystkim do obowiązków państwa. 
Polski ustawodawca powinien rozważyć umożliwienie Polakom oszczędzania w OFE w ramach III filaru, wzorem chilijskiego systemu emerytalnego. Nie ulega wątpliwości, że po obniżeniu limitu opłat pobieranych przez fundusze do $1,75 \%$ składki, stały się one nawet kilkukrotnie niższe od opłat pobieranych przez fundusze inwestycyjne działające na wolnym rynku. Jako że OFE oferują podobne co do swej istoty strategie inwestycyjne jak fundusze akcji, a ponadto są często zarządzane przez tych samych ubezpieczycieli, to dla ubezpieczonego znacznie korzystniejsze byłoby ulokowanie wolnego pieniądza właśnie za pośrednictwem tych podmiotów. Odbyłoby się to również z korzyścią dla samych OFE, które mogłyby zrekompensować sobie ubytek środków spowodowany najnowszą reformą emerytalną.

Przykład Węgier pozwala przewidzieć, że gdyby niewystarczająca liczba ubezpieczonych zdecydowała się na pozostanie w OFE, mogłoby to poskutkować wycofaniem się PTE i funduszy z rynku, co doprowadziłoby do likwidacji II filaru mocą faktów dokonanych. W związku z czym powyższy postulat umożliwienia ubezpieczonym nadpłacania składki do OFE staje się tym bardziej trafny, gdyż mógłby on zapobiec hipotetycznemu wycofaniu się funduszy emerytalnych z rynku.

Jeśli chodzi o wysokość minimalnej emerytury, to świadczenie na poziomie 450 zł oferowane przez Węgry, biorąc pod uwagę wysoką składkę emerytalną 33\% oraz wysokie podatki ogólne (np. podatek VAT w wysokości 27\%), jest niebywale niskie. Niewysoka jest również emerytura podstawowa wypłacana w Chile w wysokości 500 zł oraz solidarnościowe uzupełnienie emerytury, umożliwiające uzyskiwanie świadczenia w wysokości 600-900 zł. Jednak ich wysokość daje się po części uzasadnić niską składką emerytalną 10\%, w całości wpływającą do prywatnych funduszy emerytalnych. Ze względu na wyższe koszty życia w obu omawianych państwach, powyższe emerytury są na poziomie poniżej minimum egzystencji. Nie pozwalają one na samodzielne utrzymanie się i zmuszają emeryta do kontynuowania aktywności zawodowej po osiągnięciu wieku emerytalnego. Wynika z tego, że nie spełniają one podstawowej funkcji emerytury, czyli zabezpieczenia przed niezdolnością do pracy z powodu ryzyka starości. Na tym tle minimalna emerytura w Polsce w wysokości 845 zł miesięcznie, przy minimum egzystencji wynoszącym około 800 zł, wydaje się rozwiązaniem dostatecznym.

W oparciu o przykład węgierskiego systemu emerytalnego można wywnioskować, że nienaruszalność środków gromadzonych obligatoryjnie przez filary kapitałowe, ustanowione mocą ustawy, jest wątpliwa. Za każdym razem, gdy dany kraj znajdzie się w sytuacji kryzysu finansów publicznych, pojawia się znaczne ryzyko, iż władza rozwiąże zaistniały problem poprzez prosty transfer środków z funduszy emerytalnych. W moim przekonaniu, jedynie w sytuacji ustanowienia filaru kapitałowego mocą Konstytucji, można by mówić o stabilności tak skonstruowanego systemu, gdyż, co do zasady, do zmiany Konstytucji 
wymagalna jest kwalifikowana większość w parlamencie albo zgoda suwerena, czyli narodu, wyrażona w ogólnokrajowym referendum.

Wydaje się, że kupowanie przez fundusze emerytalne obligacji skarbowych powinno zostać zakazane. Prowadzi to do jałowego obiegu pieniądza. De facto utrzymywanie tej części filara kapitałowego nie różni się w swej istocie od filara repartycyjnego, ponieważ w ostateczności to i tak Skarb Państwa, wykupując swoje papiery dłużne, finansuje wypłatę emerytur. $Z$ tą różnicą, że świadczenia są w tym wypadku znacznie mniejsze, bo okrojone o opłatę dla funduszy.

$\mathrm{Na}$ koniec warto przytoczyć konstrukcje, które mogą z korzyścią zostać zaadaptowane przez inne państwa posiadające obligatoryjny kapitałowy system emerytalny. W mojej ocenie są to: mechanizm konkursu opłat, promujący fundusze pobierające najniższe koszty za inwestowanie środków ubezpieczonych oraz zwiększenie kontroli nad funduszami poprzez ustanowienie co najmniej jednego niezależnego członka rady nadzorczej dla każdego z nich. W ten sposób stawianie surowszych wymogów funduszom przez ustawodawcę przełoży się na większe korzyści ubezpieczonych.

Ostateczna analiza filarów kapitałowych węgierskiego i chilijskiego systemu emerytalnego prowadzi do konkluzji, iż największym beneficjentem prywatyzacji systemów emerytalnych okazały się, w większości zagraniczne (przede wszystkim amerykańskie), instytucje finansowe. Aby stworzyć efektywny filar kapitałowy konieczne jest położenie nacisku na dobro przyszłych emerytów, ograniczając opłaty funduszy, czy rozwój rynku kapitałowego. Tym bardziej, że przerost sektora finansowego był jedną z głównych przyczyn ogólnoświatowego kryzysu gospodarczego zapoczątkowanego w 2007 r.

\section{Bibliografia}

\section{Literatura}

Orędziak L., OFE katastrofa prywatyzacji emerytur w Polsce, Instytut Wydawniczy Książka i Prasa 2014.

\section{Źródla internetowe}

Ferensztajn A., Wegierski minister gospodarki: ZUS albo nic, „Forbes”, 26.11.2010, https://www. forbes.pl/wiadomosci/wegry-likwiduja-drugi-filar/n4nz36y (dostęp: 16.11.2017).

Hirose K., Hungary, CANPI-ONYF - Information on the major benefit regulations and organizational structure of the pension insurance system in Hungart, Central Administration of National Pension Insurance, sierpień 2012, http://www.onyf.hu/en/?module-news\&onyf_en_left_kozlemenyek\&root=ONYF (dostęp: 16.11.2017).

Radwan A., Mężyk R., Likwidacja OFE: kazus węierski a prywatny system emerytalny, „Rzeczpospolita”, 12.09.2013, http://www.rp.pl/artykul/10478104-Likwidacja-OFE--kazus -wegierski-a-prywatny-system-emerytalny.html\#ap-1 (dostęp: 16.11.2017). 
Shelton A. M., Chile's Pension System: Background in Brief, Analyst in Income Security, 28.03.2012, http://www.google.pl/url?sa=t\&rct=j\&q=chile\%E2\%8089797\%99s\%20 pension $\% 20$ system $\% 3 \mathrm{~A} \% 20$ background $\% 20$ in $\% 20$ brief $\% 20$ alison $\% 20 \mathrm{~m} . \% 20$ shelton $\% 20$ analyst $\% 20 \mathrm{in} \% 20$ income $\% 20$ security $\% 20$ march $\% 2028 \% 2 \mathrm{C} \% 20$ $2012 \&$ source $=$ web \& $c d=1 \& v e d=0 C \operatorname{CojAA} \& u r l=h t t p \% 3 \mathrm{~A} \% 2 \mathrm{~F} \% 2 \mathrm{Fwww}$. hsdl.org\%2F\%3Fview\%26did\%3D707798\&ei=TNaUboHMfhtQa33YBI\&usg=AFQjCNE58G0B18aAF3ZOfkj89tj1Fh3MWw\&bvm=bv.47883778,d.ZWU\&cad=rja (dostęp: 16.11.2017). 